\title{
Analysis of the Relationship of Knowledge and Attitude of Pregnant Mothers with Utilization of MCH Book
}

\author{
Gusti Ayu Gita Maharani ${ }^{1}$, Pirlina Umiastuti ${ }^{1,2 *}$, Euvanggelia Dwilda Ferdinandus ${ }^{1}$ \\ ${ }^{1}$ Department of Midwifery Education, Faculty of Medicine University Airlangga 60132, Surabaya, East Java, Indonesia \\ ${ }^{2}$ Department of Public Health Sciences-Preventive Medicine, Faculty of Medicine University Airlangga 60132, Surabaya, East Java, \\ Indonesia \\ Corresponding Author : pirlina-u@ fk.unair.ac.id
}

\begin{abstract}
Background Global maternal mortality data in 2017 was 295,000 maternal deaths. Efforts to minimize maternal mortality can be made by maximizing quality pregnancy care to ensure the condition of the mother and fetus are in good health. MCH handbooks for pregnant women are an essential tool during pregnancy. This study aims to determine the relationship between knowledge and attitudes of pregnant women about MCH books with the use of MCH books for pregnant women. Methods This type of research is an analytic study with a crosssectional observational research design. The sample of 48 pregnant women respondents and data analysis using Chi-Square test. Results: The results showed that pregnant women who had good knowledge were $21 \%$ and $79 \%$ sufficient, positive attitudes were $48 \%$ and negative attitudes were $52 \%$, and on the use of MCH books, pregnant women who used $\mathrm{MCH}$ books were $52 \%$ and did not use $\mathrm{MCH}$ books. $\mathrm{MCH}$ as much as $48 \%$. Results of the Chi-Square test showed that there was a relationship between knowledge and the use of MCH books with $\mathrm{p}=0.39(>0.05)$ and the relationship between attitudes and the use of MCH books with $\mathrm{p}=0.00(<0.05)$. Conclusion The data shows no relationship between knowledge of pregnant women about MCH books and the use of $\mathrm{MCH}$ books for pregnant women. There is a relationship between attitudes of pregnant women about $\mathrm{MCH}$ books and the use of $\mathrm{MCH}$ books for pregnant women.
\end{abstract}

Keywords: Knowledge; Attitude; MCH Handbook; Utilization

\section{Introduction}

Global maternal mortality data in 2017 was around 295,000 maternal deaths, with a maternal mortality rate of 211 per 100,000 live births (World Health Organization, 2019). In Indonesia, the number of maternal deaths in 2019 was 4,221 cases, with a maternal mortality rate of 305 per 100,000 live births. (Kemenkes RI, 2019). Meanwhile, there was an increase in maternal mortality to 110 cases in the Lampung province, with a maternal mortality rate of 75 per 100,000 live births (Dinas Kesehatan Provinsi Lampung, 2019). Efforts to minimize maternal mortality can be made by maximizing quality pregnancy care to detect early abnormalities experienced by pregnant women. (OPD Dinas Kesehatan Provinsi Lampung, 2019)

In improving mothers' understanding of pregnancy care, monitoring early detection, and ensuring that the health services they receive are met, the use of $\mathrm{MCH}$ handbooks for pregnant women is an essential tool during pregnancy. (Kemenkes RI, 2019) The MCH handbook can be used for recording maternal and child health, implementing health monitoring, and providing communication facilities by health workers and patients. The information contained in this MCH book is in the form of information on nutrition, maternal and child health, cards for pregnant women, KMS for infants and toddlers, and records of services by health workers written so 
that mothers and families know about it their health conditions. (Maharani and Rahimah, 2019)

According to theory, changing or adopting a new behavior will follow several stages through several change processes: knowledge, attitudes, and practices, or called "KAP" (PSP). However, several studies provide the opposite statement that positive behavior can occur even though knowledge and attitudes are negative. (MRL, Jaya and Mahendra, 2020) This study aims to determine the relationship between knowledge and attitudes of pregnant women about the $\mathrm{MCH}$ book and the use of $\mathrm{MCH}$ books for pregnant women at the Way Kandis inpatient Health Center in Bandar Lampung city.

\section{Method}

This type of research is analytic. The research design used was observational cross-sectional. The population in this study were all pregnant women in Bandar Lampung who did ANC checks and had a KIA book at the Way Kandis Inpatient Health Center and would plan to give birth in Bandar Lampung. The sampling technique used in this research is total sampling. The number of respondents obtained during the study was 48 pregnant women respondents. The time of the study is September-October 2021. The instrument in this study used a questionnaire. Data processing is used by editing, coding, scoring, data entry/processing, and tabulating. The collected data is processed using the Chi-Square test using the software.

\section{Result}

3.1 Based on the Characteristics of Respondents

a) Age of Respondent

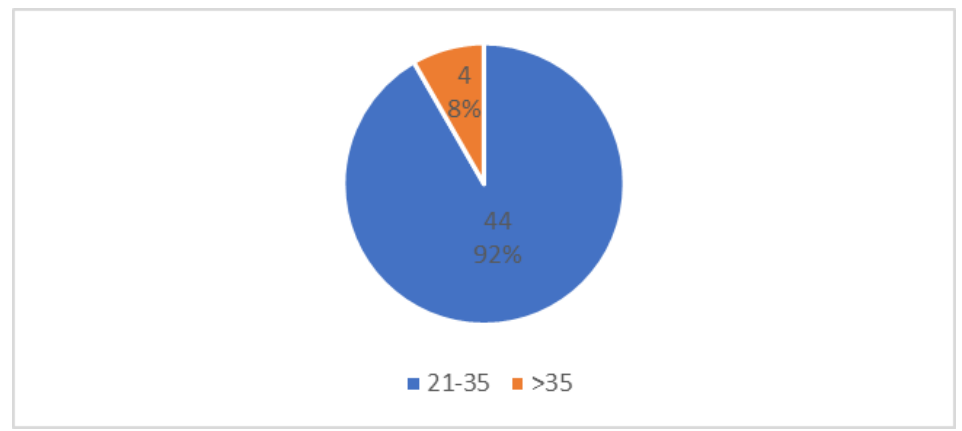

Fig. 1. Frequency distribution of pregnant women by age

Fig. 1. shows that almost all pregnant women, 44 pregnant women (91.7\%), are between 21-35 years old 
b) Last Education

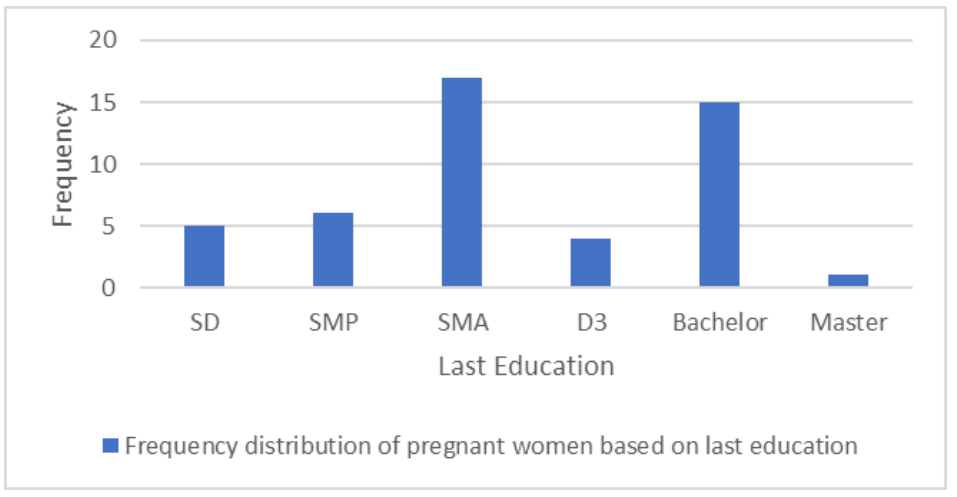

Fig. 2. Frequency distribution of pregnant women based on their last education

Fig. 2. shows that a small proportion of pregnant women have the same last education at the high school level, with a total of 17 pregnant women (35\%)

b) Occupation

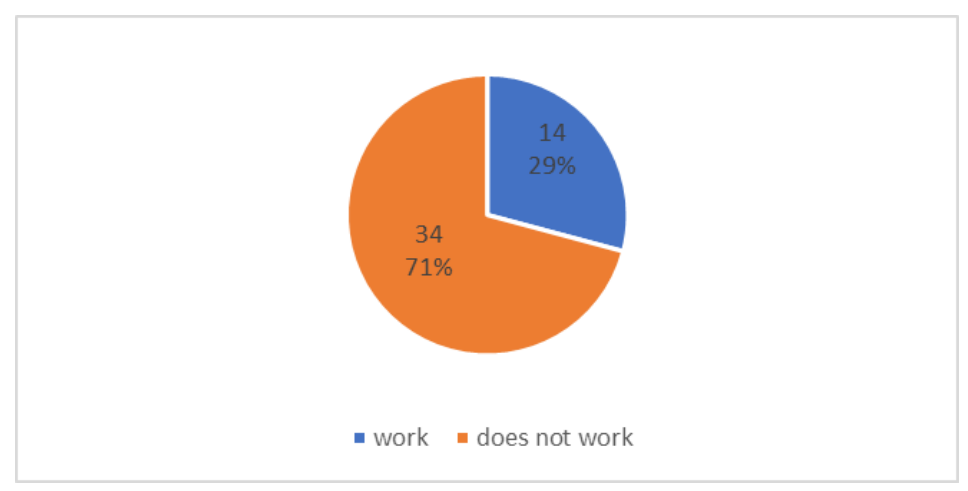

Fig. 3. Frequency Distribution of Pregnant Women by Occupation

Fig. 3. shows that more than half of respondents, 34 pregnant women (71\%) pregnant women do not work 
d) Parity

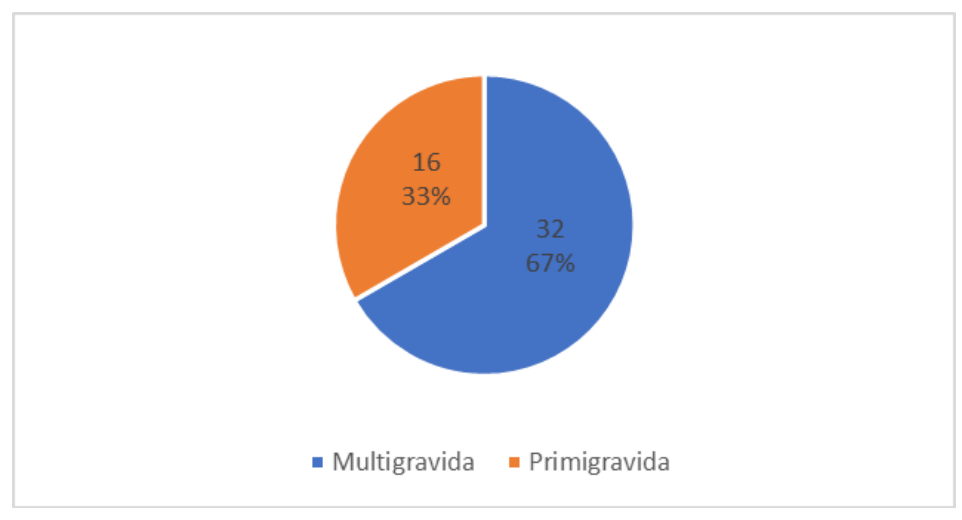

Fig. 4. Frequency Distribution of Pregnant Women by Parity

Fig. 4. shows that most respondents are 32 pregnant women (67\%) multigravida.

3.2 Knowledge of MCH Handbook

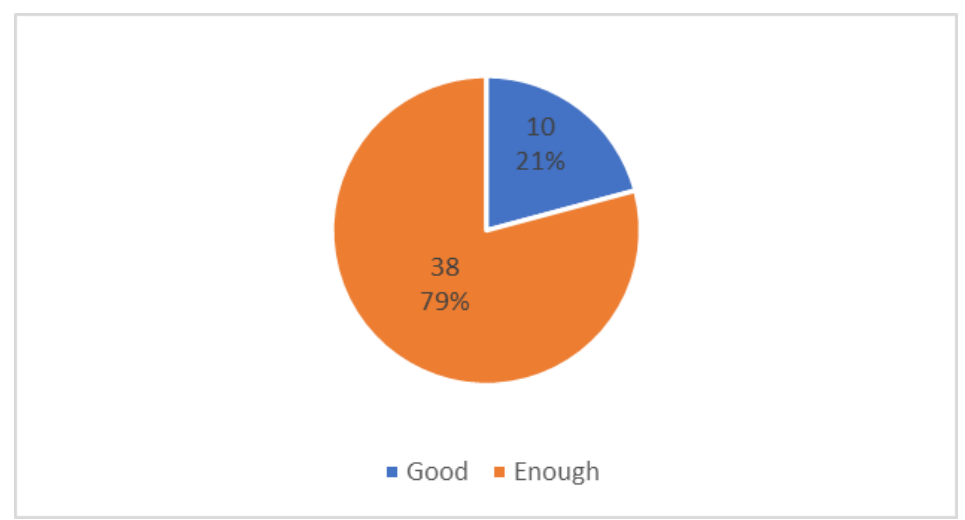

Fig. 5. Frequency Distribution of Pregnant Women's Knowledge of MCH Handbooks

Fig. 5. shows that about 38 pregnant women (79\%) have enough knowledge.

3.3 Attitudes about MCH Handbook 


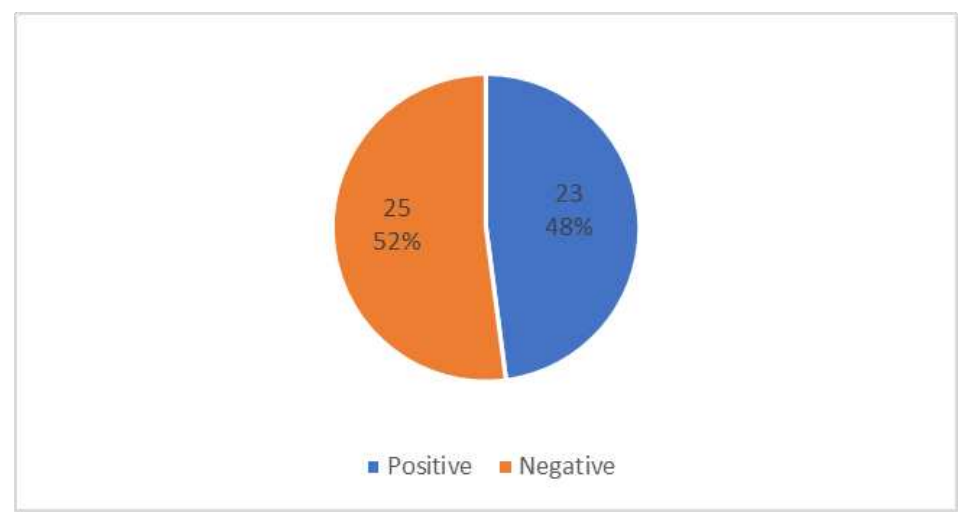

Fig. 6. Frequency Distribution of Pregnant Women's Knowledge of MCH Handbooks

Fig. 6. shows that some pregnant women, as many as 25 pregnant women (52\%), have a negative attitude towards the $\mathrm{MCH}$ handbook.

\subsection{Utilization of MCH Handbook}

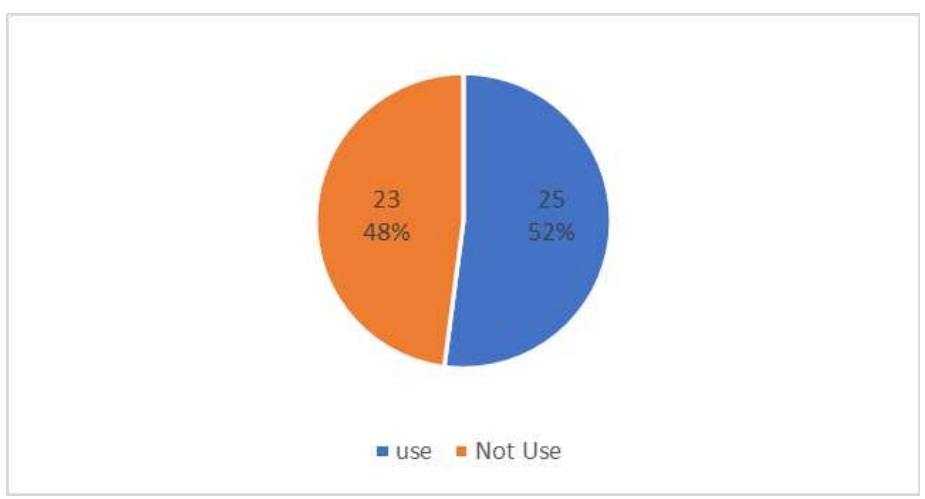

Fig. 7. Frequency Distribution of MCH Handbook Utilization

Fig. 7. shows that some pregnant women, 25 pregnant women (52\%), use the MCH book

3.5 Relationship of Knowledge with Utilization of MCH Handbook

Table 1. Relationship between Knowledge and Utilization of MCH Handbook

\begin{tabular}{|c|c|c|c|c|c|c|c|}
\hline \multirow{3}{*}{ Knowledge } & \multicolumn{4}{|c|}{ Utilization } & \multicolumn{2}{|c|}{ Total } & \multirow[t]{3}{*}{ P-value } \\
\hline & \multicolumn{2}{|c|}{ Use } & \multicolumn{2}{|c|}{ Not Use } & \multirow[b]{2}{*}{$\mathrm{F}$} & \multirow[b]{2}{*}{$\%$} & \\
\hline & $\mathrm{F}$ & $\%$ & $\mathrm{~F}$ & $\%$ & & & \\
\hline Good & 4 & 40 & 6 & 60 & 10 & 100 & \multirow{3}{*}{0,39} \\
\hline Enough & 21 & 55 & 17 & 45 & 38 & 100 & \\
\hline Total & 25 & 52 & 23 & 48 & 48 & 100 & \\
\hline
\end{tabular}


Table 1 shows the results of the statistical analysis carried out using the chi-square test, obtained a pvalue of 0.39 ( $p>0.05$ ), which means that there is no relationship between knowledge of pregnant women about $\mathrm{MCH}$ books and the use of $\mathrm{MCH}$ books for pregnant women.

3.6 Relationship between Attitude and Utilization of MCH Handbook

Table 2. Relationship of Attitudes about MCH Handbooks and Utilization of MCH Handbooks

\begin{tabular}{ccccccccc}
\hline Attitude & \multicolumn{4}{c}{ Utilization } & \multicolumn{2}{c}{ Total } & P & Contingency \\
& \multicolumn{2}{c}{ Use } & \multicolumn{2}{c}{ Not Use } & & & value & Coefficient \\
& F & $\%$ & F & $\%$ & F & $\%$ & & \\
\hline Positive & 18 & $78 \%$ & 5 & $22 \%$ & 23 & $100 \%$ & \multirow{2}{*}{0,000} & 0,449 \\
Negative & 7 & $28 \%$ & 18 & $72 \%$ & 25 & $100 \%$ & & \\
Total & 25 & $52 \%$ & 23 & $48 \%$ & 48 & $100 \%$ & & \\
\hline
\end{tabular}

Table 2 shows the results of the statistical analysis carried out using the chi-square test, obtained a pvalue of $0.00(p<0.05)$, which means that there is a relationship between the attitudes of pregnant women about the $\mathrm{MCH}$ book and the use of $\mathrm{MCH}$ books in pregnant women with a contingency coefficient of 0.45 . The strength of the relationship is moderate.

\section{Discussion}

The age of the respondents in this study was dominant in the age range of 21-35 years, namely in a healthy reproductive age. Most of the respondents in this study, namely $67 \%$ of pregnant women, were multigravida who had been pregnant and given birth before. A person's experience can be used to gain knowledge by repeating past experiences in solving problems encountered before. (Notoatmodjo, 2012)

The study results in fig. 5. show that pregnant women have sufficient and good knowledge. Most pregnant women have enough knowledge, namely 38 pregnant women (79\%). Increased knowledge possessed can come from the process of pregnant women who often read. In addition, a person's ability is influenced by the level of education they have, personal experience, and access or information opportunities they have. (Notoatmodjo, 2012) If someone can get a lot of information, the more comprehensive her knowledge. However, if someone has low awareness of using the given guide media, then that person's knowledge will not increase. (Evrianasari, 2016)

The results obtained in fig. 6. show pregnant women with positive and negative attitudes. More than 25 pregnant women $(52 \%)$ negatively attitude towards the $\mathrm{MCH}$ handbook. The negative attitude that pregnant women have can come from the mother's experience in previous pregnancy care. Mothers who have had bad experiences with prior pregnancies will negatively affect future pregnancies. (Trisnawati and Darwanty, 2020)

Some pregnant women who use the MCH handbook include 25 pregnant women $(52 \%)$. The use of the $\mathrm{MCH}$ book can occur when the pregnant woman understands the benefits contained in the MCH book. thus, motivating pregnant women to use $\mathrm{MCH}$ books by bringing $\mathrm{MCH}$ books in knowing the development of maternal and infant health. (Astari and Kirani, 2020) The form of utilization carried out by pregnant women is related to several variables such as education, attitudes, support for health workers, support for health cadres, and support from families. (Farida, 2016) In this research, mothers who have higher education levels are more dominant. For mothers with a high level of education, attitudes, and beliefs, it will be easier to receive information and the higher the awareness of mothers using and utilizing MCH books. (Subiyatun, 2017)

The statistical analysis results on the knowledge and utilization variables obtained a p-value of 0.39 
( $p>0.05$ ), which indicates that knowledge of pregnant women about MCH books has no relationship with the use of MCH books in pregnant women. The results of this study are not in line with various studies that have been carried out previously, which state that there is a relationship between knowledge and the use of $\mathrm{MCH}$ books. (Sulistiyaningsih, 2019) Other studies state a relationship between knowledge and the use of MCH books with a p-value of 0.039. (Astari and Kirani, 2020) However, there is a study whose research results explain no relationship between the level of knowledge of pregnant women about $\mathrm{MCH}$ books and the use of $\mathrm{MCH}$ books, with a p-value of 1.00 ( $\mathrm{p}>0.05)$. (Rahmi, Darma and Zaimy, 2018)

Table 1 explains that out of 10 people who have good knowledge, 6 pregnant women $(60 \%)$ do not use the $\mathrm{MCH}$ handbook. Mothers with good knowledge will assist mothers in utilizing the MCH book they have, namely by reading and applying the information contained in the $\mathrm{MCH}$ book, which includes early detection during pregnancy. However, not all pregnant women with good knowledge take advantage of the $\mathrm{MCH}$ handbook. When the mother's knowledge about the $\mathrm{MCH}$ book is good, it will make the mother think that the known information is sufficient and there is no need to use the MCH book by re-reading it or inviting her husband and family to read the MCH book. (Hanum and Safitri, 2018)

In table 2, the statistical analysis results were obtained from the Chi-Square test with a p-value of 0.00 (p $<0.05$ ), which means that there is a relationship between the attitudes of pregnant women about the MCH book and the use of MCH books for pregnant women. These results are in line with various previous studies. One of them is research that states a relationship between attitudes and the use of MCH books in pregnant women with a p-value of $0.01(p<0.05)$. (Farida, 2016) In addition, other studies have the same results and state that there is a relationship between the attitude of pregnant women and the use of $\mathrm{MCH}$ books with p-value $=0.001$ ( $\mathrm{p}$ $<0.05$ ). (Hanum and Safitri, 2018)

Several factors such as situational factors, norms, roles, and culture that are owned will determine the relationship between a person's attitude and behavior. (Oktarina and Mugeni, 2015) A positive attitude will motivate a person to use the $\mathrm{MCH}$ handbook by bringing the $\mathrm{MCH}$ book with him every time he examines a health facility. On the other hand, pregnant women who have a negative attitude will be less likely to take advantage of the $\mathrm{MCH}$ handbook by not bringing the $\mathrm{MCH}$ book with them during the prenatal check-up. Occupational factors can encourage mothers to have negative attitudes because they feel tired and forget. Then the assumption that the examination of pregnant women will continue if they do not bring the MCH handbook is also a reason for pregnant women not to get the $\mathrm{MCH}$ book in carrying out the pregnancy check-up. (Rahmi, Darma and Zaimy, 2018)

A study conducted at the Way Kandis Inpatient Health Center, also described in table 2, shows that from 23 pregnant women who have a positive attitude, 18 pregnant women $(78 \%)$ use the MCH handbook. Meanwhile, of the 25 pregnant women who had a negative attitude, 18 pregnant women $(72 \%)$ did not use the $\mathrm{MCH}$ handbook. This result is in line with previous research that stated that a positive attitude towards pregnant women would encourage expectant women to use $\mathrm{MCH}$ books and a negative attitude related to pregnant women not using $\mathrm{MCH}$ books.

\section{Conclusion}

The conclusion from the research that has been carried out is that there is no relationship between knowledge of pregnant women about $\mathrm{MCH}$ books and the use of $\mathrm{MCH}$ books, and there is a relationship between attitudes and the use of MCH books. The author is aware of the shortcomings of this study. Future research can be studied more deeply related to the negative attitudes of pregnant women and an innovation that can help increase awareness of pregnant women about the use of MCH books. It is hoped that this research can encourage health institutions and health workers, especially midwives, to understand pregnant women's importance of $\mathrm{MCH}$ books through counseling. 


\section{Acknowledgements}

Thank you to the head of the Public health center, coordinating midwife, and other health workers at the Way Kandis Inpatient Health Center who have given permission and assistance during the study's implementation and pregnant women who have participated in this study.

\section{References}

Astari, R.Y. and Kirani, T. (2020) "Hubungan Tingkat Pengetahuan dengan Pemanfaatan Buku Kesehatan Ibu dan Anak (KIA) pada Ibu Hamil,” Jurnal Riset Kesehatan, 12(2), p. 366. doi:10.34011/juriskesbdg.v12i2.1786.

Dinas Kesehatan Provinsi Lampung (2019) Profil Kesehatan Provinsi Lampung tahun $2019 . \quad$ Available at: https://dinkes.lampungprov.go.id/download/profil-kesehatan-lampung-tahun-2019/

Evrianasari, N. (2016) "Gambaran Pengetahuan Ibu Hamil tentang Buku Kesehatan Ibu dan Anak (KIA) di BPS Sulasmi SST Rajabasa Bandar Lampung,” Jurnal Kesehatan, VII(1), pp. 97-100.

Farida, N. (2016) "Determinan Pemanfaatan Buku Kesehatan Ibu dan Anak (KIA) oleh Ibu Hamil di Puskesmas Wanakerta Kabupaten Karawang Tahun 2015," The Southeast Asian Journal of Midwifery , 2(1), pp. 33-41.

Hanum, R. and Safitri, M.E. (2018) "Hubungan Pengetahuan dan Sikap Ibu Hamil tentang Pemanfaatan Buku KIA di Puskesmas Namu Ukur," Jurnal Bidan Komunitas, 1(3), pp. http://ejournal.helvetia.ac.id/index.php/jbk/article/download/3968/138

Kemenkes RI (2019) Profil Kesehatan Indonesia 2019. Available at: https://pusdatin.kemkes.go.id/resources/download/pusdatin/profilkesehatan-indonesia/Profil-Kesehatan-indonesia-2019.pdf

Maharani, K. and Rahimah, N. (2019) "Determinan Pemanfaatan Buku Kesehatan Ibu dan Anak (KIA) pada Ibu Hamil di Puskesmas Karangayu Kota Semarang," Jurnal Kesehatan STIKES Telogorejo, XI(2), pp. 69-75. Available at: http://182.253.197.100/ejournal/index.php/jikk/article/view/799

MRL, A., Jaya, I.M.M. and Mahendra, D. (2020) Buku Ajar Promosi Kesehatan. Jakarta: Fakultas Vokasi Universitas Kristen Indonesia. Notoatmodjo, S. (2012) Promosi kesehatan dan perilaku kesehatan. Rineka Cipta.

Oktarina and Mugeni (2015) "Hubungan Pengetahuan, Sikap, Kepatuhan Ibu Hamil dan Ibu Bayi dalam Penggunaan Buku KIA di Puskesmas Geger dan Kedundung Kabupaten Bangkalan, Jawa Timur, Tahun 2013," Buletin Penelitian Sistem Kesehatan, 18(2), pp. 141-150. Available at: http://ejournal.litbang.kemkes.go.id/index.php/hsr/article/download/4312/3990

OPD Dinas Kesehatan Provinsi Lampung (2019) Rencana Strategi OPD Dinas Kesehatan Provinsi Lampung 2019-2024.

Rahmi, L., Darma, I.Y. and Zaimy, S. (2018) "Faktor-Faktor yang Berhubungan dengan Pemanfaatan Buku KIA,” JIK, 2(1).

Subiyatun, S. (2017) “Gambaran Pemanfaatan Buku Kesehatan Ibu dan Anak (KIA) Oleh Ibu Hamil,” Jurnal Kebidanan dan Keperawatan, 13(2), pp. 203-209. Available at: https://kip.unisayogya.ac.id/ejournal/index.php/jkk/article/download/403/203

Sulistiyaningsih, S.H. (2019) “Hubungan Pengetahuan dan Persepsi Ibu Hamil dengan Pemanfaatan Buku KIA,” Jurnal Ilmu Keperawatan dan Kebidanan, 10(2), pp. 322-329.

Trisnawati, I. and Darwanty, J. (2020) "Kajian Faktor Determinan terhadap Pengetahuan dan Sikap Ibu Hamil Trimester III dalam Penggunaan Buku KIA Di Kabupaten Karawang," Jurnal Penelitian Kesehatan Suara Forikes, 11, pp. 153-158. doi: $10.33846 / \mathrm{sf} 11 \mathrm{nk} 428$.

World Health Organization (2019) Trends in maternal mortality 2000 to 2017 estimates by WHO, UNICEF, UNFPA, World Bank Group and the United Nations Population Division. World Health Organization. Available at: https://www.who.int/reproductivehealth/publications/maternal-mortality-2000-2017/en/ 